\title{
Ascophyllum nodosum in the diet of tilapia (Oreochromis niloticus) and its effect after inoculation of Aeromonas hydrophila ${ }^{1}$
}

\author{
Samira T.L. Oliveira², Gisele Veneroni-Gouveia ${ }^{2}$, Augusto C. Santos ${ }^{2}$, Silia M.N. Sousa ${ }^{2}$, \\ Marcelo L. Veiga ${ }^{3}$, Cristina C. Krewer ${ }^{3}$ and Mateus M. Costa ${ }^{2 *}$
}

\begin{abstract}
Oliveira S.T.L., Veneroni-Gouveia G., Santos A.C., Sousa S.M.N., Veiga M.L., Krewer C.C. \& Costa M.M. 2014. Ascophyllum nodosum in the diet of tilapia (Oreochromis niloticus) and its effect after inoculation of Aeromonas hydrophila. Pesquisa Veterinária Brasileira 34(5):403-408. Laboratório de Microbiologia e Imunologia Animal, Universidade Federal do Vale do São Francisco, Campus Ciências Agrárias, Colegiado Acadêmico de Zootecnia, Rodovia BR-407 Km 12, Lote 543, Projeto de Irrigação Nilo Coelho s/n, C1, Petrolina, PE 56300-000, Brazil. E-mail: mateus.costa@univasf.edu.br

The objective of this study was to evaluate the effect of Ascophyllum nodosum brown seaweed meal (FAM) on the health of Nile tilapia submitted to inoculation with Aeromonas hydrophila. The experiment was conducted for a period of 40 days using 120 Nile tilapia fingerlings, with age of 40 days, distributed in 20 tanks. A diet including Ascophyllum nodosum seaweed meal at $20 \mathrm{~g} \cdot \mathrm{kg}^{-1}$ and a control diet (without FAM) were provided which constituted the treatments. Thirty days after beginning the experiment, A. hydrophila was inoculated by bacterial inoculum diluted in sterile saline solution at a concentration of $10^{6}$ CFU ml-1. Except for the width, which was greater for the treatment with the provision of FAM $(\mathrm{P}<0.05)$, there was no influence on the performance parameters of the fingerlings, but the occurrence of lesions in animals inoculated with $A$. hydrophila and fed with FAM was lower and they also exhibited a decline in the lesions in a shorter period of time than the control group. FAM prevents hepatopancreatic congestion in infected animals. Ascophyllum nodosum brown seaweed meal reduced the number of lesions in fish in a shorter time when compared to the control group.
\end{abstract}

INDEX TERMS: Oreochromis niloticus, tilapia, fish, Ascophyllum nodosum, antimicrobials, Aeromonas hydrophila, aquaculture.

RESUMO.- [Ascophyllum nodosum na dieta de tilapia (Oreochromis niloticus)e o efeito dela depois da inoculação com Aeromonas hydrophila.] 0 objetivo desse estudo foi avaliar o efeito da farinha de alga marinha marrom Ascophyllum nodosum (FAM) em alevinois de tilápias do Nilo sob desafio sanitário com inoculação de Aeromonas hydrophila. 0 experimento foi realizado durante um perío-

\footnotetext{
${ }^{1}$ Received on January 25, 2014.

Accepted for publication on April 14, 2014.

${ }^{2}$ Laboratório de Microbiologia e Imunologia Animal, Universidade Federal do Vale do São Francisco (Univasf), Campus Ciências Agrárias, Colégio Acadêmico de Zootecnia, Rodovia BR-407 Km 12, Lote 543, Projeto de Irrigação Nilo Coelho s/n, C1, Petrolina, PE 56300-990, Brazil. *Corresponding author: mateus.costa@univasf.edu.br

${ }^{3}$ Laboratório de Histofisiologia Experimental, Departamento de Morfologia, Universidade Federal de Santa Maria, Av. Roraima, Prédio 19, Cidade Universitária, Santa Maria, RS 97105-900, Brazil.
}

do de 40 dias com a utilização de 120 alevinos de tilápia do Nilo, distribuídos em 20 aquários. Foi fornecida uma ração com inclusão da farinha da alga marinha Ascophyllum nodosum a 20g.kg ração ${ }^{-1}$ e uma ração testemunha (sem FAM), que constituiram os tratamentos. Após 30 dias experimentais foi realizada a inoculação de Aeromonas hydrophila por meio de um preparado de inóculo bacteriano com diluição em solução salina estéril a concentração de 106 UFC/ml. Exceto para a largura, que foi maior para o tratamento com o fornecimento da FAM $(\mathrm{P}<0,05)$, não houve influência sobre parâmetros de desempenho dos alevinos, mas a ocorrência de lesões nos animais inoculados com $A$. hydrophila e alimentados com FAM foi menor e, eles também exibiram um declínio das lesões em um menor período de tempo em relação ao grupo controle. FAM impediu a congestão hepatopancreática em animais infectados. A farinha de alga marinha marrom Ascophyllum nodosum reduziu o número 
de lesões nos peixes em menor tempo quando comparado ao controle.

TERMOS DE INDEXAÇÃO: Oreochromis niloticus, tilapia, peixe, Ascophyllum nodosum, antimicrobianos, Aeromonas hydrophila, aquicultura.

\section{INTRODUCTION}

With the growth in fishery development, increased occurrence of diseases in fish is evident since intensive farming systems favor factors that affect the homeostasis of animals (Pavanelli et al. 2008). Epizootic outbreaks are frequently observed and bacteria, among various pathogens, probably constitute the most economically significant group of etiologic agents (Frerichs \& Miller 1993). Among these agents, bacteria of the Aeromonas genus stand out. The involvement of Aeromonas in disease is usually associated with other conditions, and its pathogenicity appears to be related to stress in already debilitated hosts.

Bacteria of the Aeromonas genus are naturally present in the aquatic ecosystem and are part of the normal microbial flora of fish (Janda \& Abbott 1998). These microorganisms can cause disease in peoikilothermic and homeothermic animals, including human (Cahill 1990). They are associated with hemorrhagic septicemia in freshwater fish (Janda \& Abbott 2010) and gastroenteritis transmitted to humans by contact and consumption of contaminated meat and water (Abdullah et al. 2003).

Infection control in fish has shown limited success in prevention or cure in aquatic environments, especially when antimicrobial drugs are used. Currently, functional foods are sought to combat the onset of these diseases, since the use of antimicrobial drugs (growth promoters) is being avoided, mainly through the imposition of trade barriers in important markets like the European Union, due to their residual effect in meats, environmental impact and possible emergence of transferable resistance.

Products derived from marine algae, such as Ascophyllum nodosum meal, are being tested in animal nutrition and functional foods. A. nodosum is a brown seaweed and its use has led to improved performance, immunity and meat quality in land animals (Branden et al. 2007, Kannan et al. 2007a, 2007b, Archer et al. 2008, Gardner et al. 2008), as well as in fish (Nakagawa et al. 1997, Alves Filho et al. 2011, Costa et al. 2013).

The purpose of this study was to evaluate the effect of Ascophyllum nodosum brown seaweed meal on the health of Nile tilapia submitted to inoculation with Aeromonas hydrophila.

\section{MATERIALS AND METHODS}

Experimental conditions. Sexually reversed 40 days old Nile tilapia fingerlings $(2.68+/-0.01 \mathrm{~g})$ were distributed in 20 tanks with $60 \mathrm{~L}$ of working volume. The fingerlings were from a commercial fish hatchery installed in Juazeiro, BA, Brazil. One hundred twenty animals were selected for the experiment. One experimental unit was considered one aquarium containing six fish.

In the first stage, the delivery of FAM was evaluated in a completely randomized experimental design with two treatments and ten replications. The treatments tested were: a supply of $20 \mathrm{~g} \mathrm{~kg}^{-1}$ diet and a control diet. In the second stage, 30 days after the beginning of the experiment, inoculation of Aeromonas hydrophila was performed in the fingerlings, and treatments consisted of four groups. One group was given the control diet and inoculated with saline solution (treatment 1); another group was also given the control diet, but the inoculum contained A. hydrophila (treatment 3); and two other groups were fed with diets containing $A$. nodosum brown algae meal, one being inoculated with saline solution (treatment 2), and other inoculated with A. hydrophila (treatment 4). This formed four treatments with five replications in a completely randomized design.

The tanks had constant aeration by means of micro-porous rocks connected to mini air compressors. Experimental management consisted of daily siphoning in the morning (7:00 a.m.) and afternoon (4:30), with the removal of $40 \%$ of the water, where in addition to exchange of water, feces and any remaining feed were also removed. Internal cleaning of the walls of the tanks was performed weekly to prevent the appearance of periphyton.

Feed. Four feeds were formulated with $30 \%$ digestible protein and 3,000 kcal of digestible energy (Table 1). For the manufactu-

Table 1. Composition of experimental feeds

\begin{tabular}{|c|c|c|}
\hline \multirow[t]{2}{*}{ Ingredients $^{\mathrm{a}}$} & \multicolumn{2}{|c|}{ g kg feed $^{-1}$} \\
\hline & Treatments 2 and 4 & Treatments 1 and 3 \\
\hline Soybean meal & 713.9 & 707.9 \\
\hline Maize & 130.0 & 167.0 \\
\hline Soybean oil & 61.0 & 50.0 \\
\hline Dicalcic phosphate & 28.0 & 28.0 \\
\hline Calcitic lime & 2.00 & 2.00 \\
\hline Ascophyllum nodosum $\mathrm{g} \mathrm{kg} \mathrm{feed}{ }^{-1}$ & 20.0 & 0.00 \\
\hline Mineral and vitaminb & 40.0 & 40.0 \\
\hline Salt & 5.00 & 5.00 \\
\hline Butylated hydroxytoluene (BHT) & 0.10 & 0.10 \\
\hline \multicolumn{3}{|c|}{$\begin{array}{l}\text { According to Rostagno et al. (2000). }{ }^{\text {b }} \text { Guaranteed levels per kilogram } \\
\text { of product: Vitamin A, 1,200,000 IU; Vitamin D3, 200,000 IU; Vita- } \\
\text { min E, 12,000mg; Vitamin K3, 2400mg; Vitamin B1, 4800mg; Vitamin } \\
\text { B2, 4800mg; Vitamin B6, 4000mg; Vitamin B12, 4800mg; folic acid, } \\
\text { 1200mg; Calcium pantothenate, 12,000mg; Vitamin C, 48,000mg; Bio- } \\
\text { tin, 48mg; Choline, 65,000mg; Niacin, 24,000mg; Fe, 10,000mg; Cu, } \\
6000 \mathrm{mg} \text {; Mn, 4000mg; Zn, 6000mg; I, 20mg; Co, 2mg; Se, 20mg. }\end{array}$} \\
\hline
\end{tabular}

re, the food ground in a $1 \mathrm{~mm}$ sieve was subsequently moistened and pelleted in an experimental electric pelletizer, and these pellets were dried in a forced air oven for $24 \mathrm{~h}$ at $56^{\circ} \mathrm{C}$. When dried, they were broken up and thus the size of the pellet was adapted to mouth of the fingerlings.

Feeding was performed three times a day, at 8:00 a.m., 12:00 noon and 5:00 p.m. at a level of 8\% of the body weight of the fingerlings. Weekly, experimental units were weighed for the adjustment of the amount of feed supplied.

Ascophyllum nodosum. FAM is provided as a fine powder, lightly cream-colored, with a characteristic smell. A quantity of 20 $\mathrm{g} \mathrm{kg}^{-1}$ of feed was provided to fingerlings (Costa et al. 2013). The percentages used in this experiment (based on natural materials) for moisture, mineral matter, organic matter, ether extract and crude protein were $9.64,22.34,77.66,2.49$, and 7.70 respectively, and the gross energy value was 2,826.99 $\left(\mathrm{kcal} \mathrm{kg}^{-1}\right.$ ) (Alves Filho et al., 2011). The nutritional values of FAM provided by the manufacturer are presented in Table 2.

Inoculation of Aeromonas hydrophila. Inoculation of Aeromonas hydrophila in Nile tilapia was performed 30 days after the start of the experiment with provision of $A$. nodosum brown alga meal in feed. 
Table 2. Chemical composition of brown seaweed meal (Ascophyllum nodosum) indicated by the manufacturer ${ }^{a}$

\begin{tabular}{lccccc}
\hline Amino acids & $(\%)$ & Vitamins & $\mathrm{ppm}$ & Minerals & $\mathrm{ppm}$ \\
\hline Alanine & 0.34 & Biotin & $0.1-0.3$ & Boron & $80-100$ \\
Arginine & 0.22 & Carotene & $30-60$ & Chome & $1-2$ \\
Aspartate & 0.53 & Folic Acid & $0.1-0.5$ & Cobalt & $<1$ \\
Cystine & 0.07 & Niacin & $10-30$ & Copper & $1-10$ \\
Glutamate & 0.71 & Riboflavin & $5-10$ & Iodine & $<1.000$ \\
Glycine & 0.30 & Tiamine & $1-5$ & Iron & $100-500$ \\
Histidine & 0.07 & Tocopherols & $15-300$ & Manganese & $10-50$ \\
Isoleucine & 0.26 & Minerals & $(\%)$ & Selenium & $3-4$ \\
Leucine & 0.38 & Phosphorus & $0.1-0.2$ & Strontium & $100-600$ \\
Lysine & 0.30 & Calcium & $1.0-2.0$ & Vanadium & $1-5$ \\
Methionine & 0.11 & Chlorine & $2.0-3.0$ & Zinc & $10-50$ \\
Phenylalanine & 0.24 & Sodium & $2.5-3.5$ & Molybdenum & $<2$ \\
Proline & 0.25 & Potassium & $1.5-2.5$ & Lead & $<1$ \\
Serine & 0.27 & Magnesium & $0.5-1.0$ & Cadmium & $<1$ \\
Threonine & 0.25 & Sulfur & $2.0-3.0$ & Carbohydrates & $(\%)$ \\
Tyrosine & 0.12 & Minerals & ppm & Alginate & $18.0-27.0$ \\
Tryptophan & 0.06 & Aluminum & $50-150$ & Mannitol & $3.0-8.0$ \\
Valine & 0.27 & Barium & $5-15$ & Laminarin & $2.0-5.0$
\end{tabular}

${ }^{a}$ Acadian Seaplants Limited.

A bacterial inoculum was prepared with dilution in sterile saline solution at a concentration of $10^{6} \mathrm{CFU} \mathrm{m}^{-1}$ and administered through right dorsal-lateral intramuscular injection in each experimental fish, just as pure saline solution was applied at a rate of $0.5 \mathrm{~mL} /$ control animal. After inoculation, the animals were held for a period of 15 days.

Measurements and experimental analysis. Every day before siphoning, the oxygen concentration, temperature, electrical conductivity and $\mathrm{pH}$ of the water in the experimental tanks were measured (multiparameter meter model HI 9828, HANNA Instruments).

To control water hygiene, the aquarium water was seeded on blood agar medium before of the inoculation procedure of $A$. hydrophila in the experimental fish. Fishes were also weighed and measured 30 days after the beginning of the experiment, and divided into treatments: provision of the control diet (treatment 1 and treatment 3) and feed containing $20 \mathrm{~g} \mathrm{~kg}^{-1}$ of FAM (treatment 2 and treatment 4 ), with ten replications in each treatment.

After inoculation, the animals were evaluated to 15 days for possible manifestations of infection by $A$. hydrophila. Evolution of lesions in fish and mortality was monitored on a daily basis. At the end of the trial period, after being anesthetized with benzocaine $\left(100 \mathrm{mg} \mathrm{l}^{-1}\right)$ and euthanized by spinal cord section, fishes in each experimental unit were weighed and measured to determine performance and carcass parameters as final weight, total length (including the caudal fin), standard length (without caudal fin), height (posterior region to operculum), weight gain and feed conversion. Two fishes from each experimental unit had their liver extracted for determination of hepatosomatic index (HSI), [(liver weight/body weight) $x$ 100] and from one of them a bacterial culture was made of the kidney using one measurement of the platinum loop sown directly in Tryptone Soy agar (TSA ).

Samples of liver were submmited to histologic routine processes for parafine and stained with Hematoxilin-Eosin (HE). Microscopic slides were evaluated according with hepatopancreatic degenerative and congestion aspects.

After all the proposed parameters were evaluated the data were subjected to variance analysis (One-way ANOVA) and when a significant effect was detected $(\mathrm{p}<0.05)$, the Tukey test was performed by the software Statistica 7.0. Histological results were evaluated with Pearson's chi-squared test.

\section{RESULTS \\ Effect of Ascophyllum nodosum before inoculation with Aeromonas hydrophila}

Aquarium water and bacterial culture. The averages for temperature, $\mathrm{pH}$, dissolved oxygen and electrical conductivity, in the morning and afternoon, were $27.28 \pm 0.06^{\circ} \mathrm{C}$ and $28.14 \pm 0.12^{\circ} \mathrm{C}, 7.24 \pm 0.04$ and $7.14 \pm 0.04,6.94 \pm 0.11$ and $6.73 \pm 0.17 \mathrm{mg} \mathrm{l}^{-1}, 68.87 \pm 2.75$ and $63.71 \pm 3.68 \mu \mathrm{Sm} \mathrm{cm}^{-1}$, respectively. There was no variation in these parameters among the treatments $(\mathrm{P}>0.05)$.

Growth and carcass characteristics. The averages of growth and carcass characteristics after 30 experimental days, of the Nile tilapia (Oreochromis niloticus) fingerlings submitted to diets containing $20 \mathrm{~g} \mathrm{~kg}^{-1}$ feed of Ascophyllum nodosum meal, are presented in Table 3.

Table 3. Averages of carcass characteristics and growth of Nile tilapia fingerlings fed with Ascophyllum nodosum diet and the control diet

\begin{tabular}{lccc}
\hline \multirow{2}{*}{ Variables } & \multicolumn{2}{c}{$\mathrm{g} \mathrm{kg}^{-1}$ of A. nodosum } & $\mathrm{P}^{*}$ \\
\cline { 2 - 4 } & 0 & 20 & \\
\hline Average initial weight $(\mathrm{g})$ & $2.69 \pm 0.012$ & $2.69 \pm 0.01$ & 0.20 \\
Average final weight $(\mathrm{g})$ & $11.03 \pm 0.97$ & $11.50 \pm 0.75$ & 0.24 \\
total length $(\mathrm{cm})$ & $8.80 \pm 0.24$ & $8.91 \pm 0.14$ & 0.23 \\
standard length $(\mathrm{cm})$ & $7.35 \pm 0.62$ & $7.36 \pm 0.12$ & 0.96 \\
Width (cm) & $1.35 \pm 0.06 \mathrm{a}$ & $1.40 \pm 0.04 \mathrm{~b}$ & 0.02 \\
Height (cm) & $2.51 \pm 0.11$ & $2.56 \pm 0.10$ & 0.34 \\
Weight gain (g) & $8.36 \pm 0.96$ & $8.81 \pm 0.75$ & 0.25 \\
Feed conversion & $1.46 \pm 0.15$ & $1.35 \pm 0.07$ & 0.06
\end{tabular}

*P = P-value.

The initial weight of the fingerlings used in the experiment had no significant effect on our analysis $(\mathrm{P}>0.05)$. The final weight, total length, standard length, height, weight gain and feed conversion were not significantly different among treatments. Width exhibited a significant effect $(\mathrm{P}<0.05)$ among treatments, and treatment with $A$. nodosum diet showed averages higher than treatment without Ascophyllum nodosum diet. The survival rate was $100 \%$ in all units during this trial period.

\section{Effect of Ascophyllum nodosum after inoculation with Aeromonas hydrophila}

Aquarium water and bacterial culture. The averages for temperature, $\mathrm{pH}$, dissolved oxygen and electrical conductivity, in the morning and afternoon were, $27.31 \pm 0.09^{\circ} \mathrm{C}$ and $28.14 \pm 0.12^{\circ} \mathrm{C}, 7.2 \pm 0.05$ and $7.14 \pm 0.05,7.14 \pm 0.15$ and $6.76 \pm 0.15 \mathrm{mg} \mathrm{l}^{-1}, 86.81 \pm 0.63$ and $82.58 \pm 4.5 \mu \mathrm{Sm} \mathrm{cm}^{-1}$, respectively. There was no variation in these parameters among treatments $(\mathrm{P}>0.05)$.

None of the aquariums presented growth of colonies of the Aeromonas genus. From the bacterial culture of the kidney through TSA derived from dead fish during the experimental period, there was growth of bacterial colonies of the Aeromonas genus; however, the same was not observed to grow from cultures derived from the kidney of the fingerlings at the end of the experiment.

Survival rate, growth and feed conversion. The averages for initial weight, final weight, weight gain, feed con- 
version and survival rate of Nile tilapia fingerlings subjected to the feed containing $20 \mathrm{~g} \mathrm{~kg}^{-1}$ of FAM and inoculation with $A$. hydrophila are shown in Table 4 . The difference in initial weights of fingerlings used in the experiment was not significant among treatments $(\mathrm{P}>0.05)$. Similarly, the final weight, weight gain, feed conversion and survival rate of the fingerlings did not exhibit significant differences among treatments $(P>0.05)$ (Table 4$)$.

Characteristics and carcass yield. The final averages for body parameters, carcass yield and hepatosomatic index (HSI) of Nile tilapia are presented in Tables 5 and 6 , respectively. The total length, standard length, width, height, carcass yield with and without head and the HSI values of the Nile tilapia fingerlings were not significantly different among treatments $(\mathrm{P}>0.05)$.

Table 4. Averages of performance parameters, feed conversion (CAA) and survival rate of Nile tilapia fingerlings

\begin{tabular}{|c|c|c|c|c|c|}
\hline \multirow[t]{2}{*}{ Variables } & \multicolumn{4}{|c|}{ Treatments $^{\mathrm{a}}$} & \multirow[t]{2}{*}{$\mathrm{P}^{*}$} \\
\hline & 1 & 2 & 3 & 4 & \\
\hline Initial weight (g) & $2.68 \pm 0.01$ & $2.69 \pm 0.00$ & $2.68 \pm 0.01$ & $2.68 \pm 0.01$ & 0.27 \\
\hline Final weight (g) & $17.38 \pm 1.95$ & $18.03 \pm 1.24$ & $16.34 \pm 1.89$ & $17.86 \pm 0.10$ & 0.36 \\
\hline Weight gain (g) & $14.70 \pm 1.94$ & $15.33 \pm 1.24$ & $13.66 \pm 1.89$ & $15.18 \pm 1.00$ & 0.36 \\
\hline CAA & $1.59 \pm 0.12$ & $1.52 \pm 0.25$ & $1.72 \pm 0.15$ & $1.69 \pm 0.16$ & 0.28 \\
\hline Survival (\%) & $96.67 \pm 7.45$ & $100.00 \pm 0.00$ & $93.33 \pm 9.13$ & $90.00 \pm 9.13$ & 0.21 \\
\hline
\end{tabular}

a (1) group receiving the control diet and inoculated with saline solution, (2) receiving diet with FAM and inoculated with saline solution, (3) group receiving the control diet and inoculated with A. hydrophila, (4) group receiving diet with FAM and inoculated with Aeromonas hydrophila. * $\mathrm{P}=\mathrm{P}$-value.

Table 5. Averages of body parameters of Nile tilapia subjected to diets containing Ascophyllum nodosum brown seaweed meal after inoculation with Aeromonas hydrophila

\begin{tabular}{lccccc}
\hline \multirow{2}{*}{ Variables } & \multicolumn{4}{c}{ Treatments $^{\mathrm{a}}$} & \multirow{2}{*}{ P* $^{*}$} \\
\cline { 2 - 5 } & 1 & 2 & 3 & 4 & \\
\hline Overall length $(\mathrm{cm})$ & $10.17 \pm 0.34$ & $10.23 \pm 0.22$ & $9.97 \pm 0.38$ & $10.33 \pm 0.21$ & 0.31 \\
Standard length $(\mathrm{cm})$ & $8.26 \pm 0.22$ & $8.33 \pm 0.21$ & $8.08 \pm 0.34$ & $8.40 \pm 0.18$ & 0.24 \\
Width $(\mathrm{cm})$ & $1.48 \pm 0.05$ & $1.51 \pm 0.05$ & $1.49 \pm 0.06$ & $1.55 \pm 0.03$ & 0.17 \\
Height $(\mathrm{cm})$ & $2.83 \pm 0.12$ & $2.93 \pm 0.08$ & $2.86 \pm 0.12$ & $2.91 \pm 0.09$ & 0.41
\end{tabular}

a (1) group receiving the control diet and inoculated with saline solution, (2) receiving diet with FAM and inoculated with saline solution, (3) group receiving the control diet and inoculated with A. hydrophila, (4) group receiving diet with FAM and inoculated with Aeromonas hydrophila. $* \mathrm{P}=\mathrm{P}$-value.

Table 6. Final averages of carcass yield and hepatosomatic index of Nile tilapia fingerlings subjected to diets containing Ascophyllum nodosum brown seaweed meal after inoculation with Aeromonas hydrophila

\begin{tabular}{lccccc}
\hline Variables & \multicolumn{4}{c}{ Treatments $^{\mathrm{d}}$} & $\mathrm{P}^{*}$ \\
\cline { 2 - 5 } & 1 & 2 & 3 & 4 & $\mathrm{P}^{*}$ \\
\hline RCCa $(\mathrm{g})$ & $15.24 \pm 1.68$ & $15.74 \pm 0.99$ & $13.98 \pm 1.44$ & $15.77 \pm 0.89$ & 0.14 \\
RCb(g) & $10.85 \pm 1.31$ & $11.28 \pm 0.76$ & $10.15 \pm 1.09$ & $11.10 \pm 0.65$ & 0.32 \\
HSIc & $2.43 \pm 0.52$ & $2.21 \pm 0.47$ & $2.04 \pm 0.49$ & $2.23 \pm 0.24$ & 0.61
\end{tabular}

a Carcass yield with head; b Headless carcass yield; $\mathrm{c}$ hepatosomatic index; d (1) group receiving the control diet and inoculated with saline solution, (2) receiving diet with FAM and inoculated with saline solution, (3) group receiving the control diet and inoculated with A. hydrophila, (4) group receiving diet with FAM and inoculated with $\mathrm{A}$. hydrophila. ${ }^{*} \mathrm{P}=$ P-value.
Evolution of the lesions caused by Aeromonas hydrophila. The analysis of the occurrence of lesions in animals inoculated with $A$. hydrophila, fed with FAM or not, showed the appearance of one lesion in the inoculation area in $58.33 \%$ of animals. After of the third day, reduction in the area of lesions in the group fed with FAM was observed. After of the seventh day it remained constant. The group fed with FAM showed a decline in the number of fishes with lesion in a shorter period of time related the control group (Fig.1).

Histological analysis. Microscopic observation showed that hepatopancreatic degeneration process was similar in all groups studied. Hepatopancreatic tissue of T3 and $\mathrm{T} 4$ animals demonstrated more congestion that $\mathrm{T} 1$ and $\mathrm{T} 2(\mathrm{P}<0.05)$ (Table 7). In relation to hepatocyte area, we observed statistical differences $(\mathrm{P}<0.05)$ in all treatments, with exception of T1 amongst T2. Considering nuclear area, only $\mathrm{T} 4$ showed statistical differences compared to the other treatments $(\mathrm{P}<0.05)$ (Table 7).

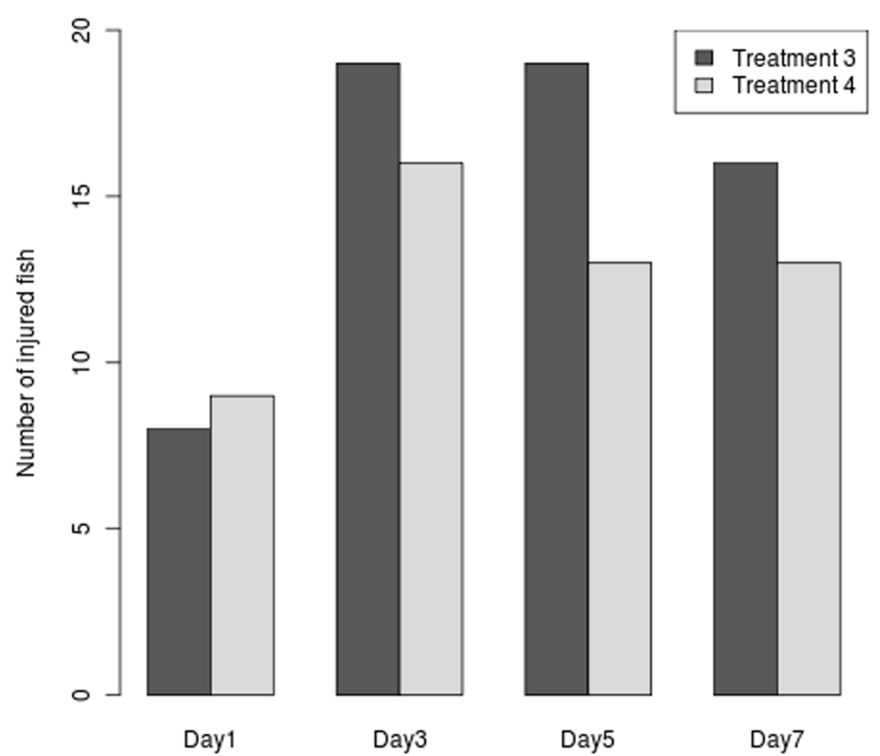

Fig.1. Evolution in the number of fishes with lesions caused by Aeromopnas hydrophila in Nile tilapia fingerlings fed (T4) or not (T3) with Ascophyllum nodusum meal.

Table 7. Morfometric parameters in hepatocytes

\begin{tabular}{lcccc}
\hline \multicolumn{1}{c}{ Parameter } & Treatment 1 & Treatment 2 & Treatment 3 & Treatment 4 \\
\cline { 2 - 5 } Hepatocyte area & $61 \pm 17 \mathrm{a}$ & $63 \pm 21 \mathrm{a}$ & $73 \pm 19 \mathrm{~b}$ & $82 \pm 23 \mathrm{c}$ \\
Hepatocyte nuclear area & $16 \pm 4.1 \mathrm{a}$ & $17 \pm 4.4 \mathrm{a}$ & $17 \pm 3.9 \mathrm{a}$ & $19 \pm 4.5 \mathrm{~b}$
\end{tabular}

Different letters indicate statistical differences $(p<0.05)$ from Anova One-Way test followed by Tukey post hoc test.

\section{DISCUSSION}

The averages of physicochemical parameters of tank water, $\mathrm{pH}$, dissolved oxygen, electrical conductivity and morning and afternoon temperatures remained within permissible limits for the species (Kubitza 2003).

In the present study, no mortality was observed in fish associated with the inoculation procedure of Aeromonas hydrophila. This was probably due to inoculation dose of 
$10^{6} \mathrm{CFU} \mathrm{ml}{ }^{-1}$ which can be considered low. In the literature, there are large discrepancies between the lethal doses described for isolates of Aeromonas spp., ranging from $10^{4}$ to $10^{12} \mathrm{CFUml}^{-1}$ (Boijink \& Brandão 2001, Boijink et al. 2001, Oliveira et al. 2011). In the present study, the inoculation dose was of great importance so as to observe the effects of Ascophyllum nodosum brown seaweed meal on the performance parameters of Nile tilapia, which would not be possible with the death of animals. The protective effects against mortality induced by Ascophyllum salmonicida in salmon fed with extracts of macroalgae were described by Nordmo et al. (1995).

After analyzing the performance and carcass parameters, no significant difference among treatments was observed. This contradicts the results described by Costa et al. (2013), who observed improved feed conversion and carcass yield. However, these authors worked with younger fish, as well as those in healthy growing conditions. There was also no significant difference reported in performance parameters in sheep fed with $A$. nodosum in a study by Fike (2005), although the authors considered that when analyzed together, the results showed benefits in digestibility of the diet. Likewise, when we analyze our results numerically, we also found positive effect upon the inclusion of FAM in the diets of animals and inoculation of A. hydrophila.

Even without causing significant mortality in fish, $A$. hydrophila led to the development of one lesion in the inoculation area, but this number of fishes with lesion declined in a shorter period of time in the group fed with FAM. This may be associated with increased activity of the immune system of fishes, which reduced the damage caused by this bacterium in the tissues. Several studies indicate the important role of $A$. nodosum as immunostimulant. In working with Atlantic salmon, Gabrielsen \& Austreng (1998) found no difference in the parameters of the final weight and growth. However, they found a positive effect on the activity of serum lysozyme. Positive effects on the immune system and resistance to stress in sheep have been described by Saker (2004).

In current fish production systems, the animals are predisposed to stress and bacterial infections. This often requires the use of antimicrobial drugs that are associated with the selection of resistant microorganisms and with the presence of residues in fish and in the aquatic environment (Verschuere et al. 2000). Antimicrobial resistance is a major point of concern in aquaculture (Guardabassi et al. 2010). The use of FAM may be useful as food additive in fish since its effects on the immune system may be important for resistance to attack by bacterial and viral pathogens (Nordmo et al. 1995, Gabrielsen \& Austreng 1998).

Animals treated with FAM demonstrated lower hepatopancreatic congestion. Since there was no statistical difference between T1 and T2, it is suggested that the FAM prevents congestion hepatopancreatic tissue in infected animals. Several authors report that hepatopancreatic changes are associated with contaminants (Dabrowska et al. 2012, Gutiérrez-Praena et al. 2012).

Alterations in cellular and nuclear area of hepatocytes were not observed on uninfected animals feed with FAM.
On the other hand, infected animals (T3 and T4) showed an increase in these characters, evidencing the high cellular synthetic activity, probably associated with production of inflammatory cytokine or detoxification enzymes, as well the increase in volume of mitochondria and lysosomes (Strmac and Braunbeck 2002, Marchand et al. 2006, Abdel-Moneim et al. 2012, Dabrowska et al. 2012, Gutiérrez-Praena et al. 2012).

\section{CONCLUSION}

It was established that although Ascophyllum nodosum brown seaweed meal does not have a significant effect on performance and carcass parameters, but reduces the number of fishes with lesion in a short period of time. Besides, FAM prevents hepatopancreatic congestion in Aeromonas hydrophila infected animals.

Acknowledgements.- To CAPES (Coordination for the Improvement of Higher Education) for granting a scholarship to Samira Teixeira Leal de Oliveira and Gisele Veneroni Gouveia. To the Integrated Center for Fishery Resources (CIRPA) from Bebedouro, PE, Brazil for providing the Nile tilapia. This study has authorization from the Ethics Committee for Research in Human and Animal Studies at the Univasf (Universidade Federal do Vale do São Francisco) under number 27091053 of October 6, 2010.

\section{REFERENCES}

Abdel-Moneim A.M., Al-Kahtani M.A. \& Elmenshawy O.M. 2012. Histopathological biomarkers in gills and liver of Oreochromis niloticus from polluted wetland environments, Saudi Arabia. Chemosphere 88(8):10281035.

Abdullah A.I., Hart C.A. \& Winstanley C. 2003. Molecular characterization and distribution of virulence associated genes amongst Aeromonas isolates from Libya. J. Appl. Microbiol. 95:1001-1007.

Alves Filho F.M., Santos L.D., Silva L.C.R., Bombardelli R.A. \& Meurer F. 2011. Brown seaweed (Ascophyllum nodosum) to Nile tilapia fingerlings. Revta Bras. Saúde Prod. Anim. 12(4):1095-1102.

Archer G.S., Friend T.H., Caldwell D., Ameiss K. \& Krawczel P.D. 2008. Effect of the seaweed Ascophyllum nodosum on lambs during forced walking and transport. J. Anim. Sci. 85:225-232.

Boijink C.L. \& Brandão D.A. 2001. Inoculation with Aeromonas hydrophila bacteria and the survival of juvenile jundiá, Rhamdia quelen (Teleostei: Pimelodida). Ciência Rural 31(3):503-507.

Boijink C.L., Brandão D.A., Vargas A.C., Costa M.M. \& Renosto A.V. 2001. Inoculation of bacterial suspension of Plesiomonas shigelloides in jundiá, Rhamdia quelen (Teleostei: Pimelodidae). Ciência Rural 31(3): 497-501.

Branden K.W., Blanton J.R., Montgomery J.L., Van Santen E., Allen V.G. \& Miller M.F. 2007. Tasco supplementation: Effects on carcass characteristics, sensory attributes, and retail display shelf-life. J. Anim. Sci. 85:754768.

Cahill M.M. 1990. Bacterial flora of fishes: a review. Microb. Ecol. 19(1):2141.

Costa M.M., Oliveira S.T.L., Balen R.E., Bueno Junior G., Baldan L.T., Silva L.C.R. \& Santos L.D. 2013. Brown seaweed meal to Nile tilapia fingerlings. Arch. Zootec. 62(237):101-109.

Dabrowska H., Ostaszewska T., Kamaszewski M., Antoniak A., NaporaRutkowski L., Kopko O., Lang T., Fricke N.F. \& Lehtonen K.K. 2012. Histopathological, histomorphometrical, and immunohistochemical biomarkers in flounder (Platichthys flesus) from the southern Baltic Sea. Ecotoxicol. Environ. Saf. 78:14-21.

El-Sayed A.M. 2006. Tilapia culture. CABI Publishing, Oxford. 277p.

FAO 2010. El Estado Mundial de la Pesca y la Acuicultura (in Spanish). Food and Agriculture Organization of United Nations, Rome. 242p. 
Fike J.H., Saker K.E., O'keefe S.F., Marriott N.G., Ward D.L., Fontenot J.P. \& Veit H.D. 2005. Effects of (a seaweed extract) and heat stress on $\mathrm{N}$ metabolism and meat fatty acids in wether lambs fed hays containing endophyte-infected fescue. Small Rumin. Res. 60:237-245.

Frerichs G.N. \& Miller S.D. 1993. Manual for the Isolation and Identification of Fish Bacterial Pathogens. Pisces Press, Stirling. 60p.

Gabrielsen B.O. \& Austreng E. 1998. Growth, product quality and immune status of Atlantic salmon, Salmo salar L., fed wet feed with alginate. Aquacult. Res. 29:397-401.

Gardiner G.E., Campbell A.J., O’Doherty J.V., Pierce E., Lynch P.B., Leonard F.C., Stanton C., Ross R.P. \& Lawlor P.G. 2008. Effect of Ascophyllum nodosum extract on growth performance, digestibility, carcass characteristics and selected intestinal microflora populations of grower-finisher pigs. Anim. Feed Sci. Technol. 141:259-273.

Guardabassi L. \& Jensen I.B. 2010. Guia de Antimicrobianos em Veterinária. Artmed, Porto Alegre. 267p.

Gutiérrez-Praena D., Jos A., Pichardo S., Moyano R., Blanco A., Monterde J.G. \& Cameán A.M. 2012. Time-dependent histopathological changes induced in Tilapia (Oreochromis niloticus) after acute exposure to pure cylindrospermopsin by oral and intraperitoneal route. Ecotoxicol. Environ. Saf. 76(2):102-13.

Janda J.M. \& Abbott S.L. 1998. Evolving concepts regarding the genus Aeromonas: an expanding panorama of species, disease presentations, and unanswered questions. Clin. Infect. Dis. 28:332-344.

Janda J.M. \& Abbott S.L. 2010. The genus Aeromonas: taxonomy, pathogeniticy and infection. Clin. Microbiol. Rev. 23:35-73.

Kannan G., Saker K.E., Terrill T.H., Kouakou B., Galipalli S. \& Gelaye S. 2007b. Effect of seaweed extract supplementation in goats exposed to simulated preslaughter stress. Small Rumin. Res. 73:221-227.

Kannan G., Terrill T.H., Kouakou B. \& Galipalli S. 2007a. Blood metabolite changes and live weight loss following brown seaweed extract supplementation in goats subjected to stress. Small Rumin. Res. 73:228-234.
Kubitza F. 2003. Qualidade da Água no Cultivo de Peixes e Camarões. Acqua Supre Com. Suprim. Aquicultura Ltda, Jundaí, SP, Brazil. 229p.

Marchand M.J., Van Dyk J.C., Pieterse G.M., Barnhoorn I.E. \& Bornman M.S. 2009. Histopathological alterations in the liver of the sharptooth catfish Clarias gariepinus from polluted aquatic systems in South Africa. Environ. Toxicol. 24(2):133-147.

Meurer F., Costa M.M., Barros D.A.D., Oliveira S.T.L. \& Paixão P.S. 2009. Brown propolis extract in feed as a growth promoter of Nile tilapia (Oreochromis niloticus Linnaeus, 1758) fingerlings. Aquacult. Res. 40:603-608.

Nakagawa H., Umino T. \& Tasaka Y. 1997. Usefulness of Ascophyllum meal as a feed additive for red sea bream, Pagrus major. Aquaculture 151: 275-281.

Nordmo R., Holth J.M. \& Gabrielsen B.O. 1995. Immunostimulating effect of alginate feed with Aeromonas salmonicida. Mol. Mar. Biol. Biotechnol. $4: 232-235$.

Oliveira S.R., Souza R.T.Y.B., Brasil E.M., Andrade J.I.A., Nunes É.S.S., Ono E.A. \& Affonso E.G. 2011. $\mathrm{LD}_{50}$ of the bacteria Aeromonas hydrophila to matrinxã, Brycon amazonicus. Acta Amazonica 41(2):321-326.

Pavanelli G.C., Eiras J.C. \& Takemoto R.M. 2008. Doenças de Peixes: profilaxia, diagnóstico e tratamento. 3a ed. Eduem, Maringá, PR, Brazil, p.311.

Rostagno H.S., Albino L.F.T., Gomes P.C., Oliveira R.F. \& Lopes D.C. 2000. Tabelas Brasileiras para Aves e Suíno: composição de alimentos e exigências nutricionais. Editora UFV, Viçosa, MG, Brazil. 141p.

Saker K.E., Fike J.H., Veit H. \& Ward D.L. 2004. Brown seaweed- Tasco $^{\mathrm{TM}}$ ) treated conserved forage enhances antioxidant status and immune function in heat-stressed wether lambs. J. Anim. Physiol. Anim. Nutr. 88:122-130

Strmac M. \& Braunbeck T. 2002. Cytological and biochemical effects of a mixture of 20 pollutants on isolated rainbow trout (Oncorhynchus mykiss) hepatocytes. Ecotoxicol. Environ. Saf. 53(2):293-304.

Verschuere L., Rombaut G., Sorgeloos P. \& Verstraete W. 2000. Probiotic bacteria as biological control agents in aquaculture. Microbiol. Mol. Biol. Rev. 64(4):655-671. 